\title{
PENDIDIKAN ESTETIKA DAN KARAKTER PEDULI LINGKUNGAN SEKOLAH
}

\author{
*Sitti Hasnidar \\ *Sitti Hasnidar adalah Guru pada SMA Negeri 8 Banda Aceh \\ Email : hasnidar.sitti@gmail.com
}

\begin{abstract}
Abstrak
Kerusakan lingkungan tidak bisa dihindari, tetapi dapat diperlambat. Upaya untuk menghambat perlu dilakukan melalui pendidikan yaitu dengan cara menumbuhkan kesadaran pentingnya menjaga kelestarian lingkungan, mengubah kebiasaan yang kurang atau belum baik menjadi kebiasaan baru yang lebih baik, lebih peduli dan berpihak pada kelestarian lingkungan. Hal itu dapat ditempuh melalui integrasi pendidikan nilai karakter yang dapat menumbuhkan kesadaran lingkungan dalam mata pelajaran. Untuk mengubah pengetahuan, sikap dan perilaku menjadi lebih baik dapat dilakukan dengan penguatan pendidikan karakter yang diintegrasikan dalam proses pembelajaran. Penelitian ini bertujuan untuk mengidentifikasi perasaan, kesadaran dan perilaku keindahan peserta didik terhadap lingkungan sekolah. Penelitian ini melibatkan peserta didik dari SMA Negeri 10 Fajar Harapan Banda Aceh tahun pelajaran 2018/2019 sebanyak 12 orang yang menjadi situs penelitian. Pengumpulan data dilakukan melalui teknik observasi, wawancara, dan dokumentasi. Hasilnya memperlihatkan, bahwa: (1) perasaan keindahan peserta didik terhadap lingkungan sekolah dapat dilihat dari kepekaan mereka pada saat memandang lingkungan sekolahnya, (2) kesadaran keindahan peserta didik terhadap lingkungan sekolah dapat dilihat dari reflektisitas mereka pada saat melihat atau merasakan keindahan lingkungan sekolahnya, (3) perilaku keindahan peserta didik terhadap lingkungan sekolah dapat dilihat dari perilaku mereka pada saat memandang atau merasakan kondisi lingkungan sekolah yang tidak sesuai dengan keindahan lingkungan.
\end{abstract}

Kata Kunci: Estetika, Karakter Peduli Lingkungan Sekolah

\section{PENDAHULUAN}

Semua penduduk bumi perlu mengambil waktu untuk berperan aktif menjaga kondisi bumi tempat hidup, tempat berpijak, tempat sumber udara untuk bernafas, tempat mencari sumber penghidupan dan kehidupan supaya bumi ini menjadi tempat hunian yang sehat, aman dan nyaman bagi semua makhluk hidup. Bumi hanya satu seharusnya tidak ada alasan untuk menunda kepedulian dan kesadaran kita untuk menjaga kelestarian bumi, agar generasi di masa depan masih dapat hidup nyaman di bumi ciptaan Allah Yang Maha Esa ini dengan sehat dalam lingkungan yang bersih dan nyaman. Kenyataannya masih saja banyak warga di seluruh dunia yang belum menyadari bahwa 
bumi, alam semesta sudah cukup lelah, sakit, dan merana karena ulah manusia. Kita tidak bisa menutup mata untuk tidak melihat, menutup telinga untuk tidak mendengar, banyak sekali masalah yang terjadi pada bumi saat ini, mulai dari pencemaran tanah, air,udara, suara dan pencemaran oleh radiasi yang setiap hari terus terjadi dan terus bertambah dan makin bertambah-tambah setiap detik, menit, jam, setiap saat tanpa henti (American Chemical Society, 2011: 277). Kerusakan bumi terus terjadi dalam setiap aktivitas kita, bahkan ketika kita sedang tidur sekalipun, perusahaan besar selalu melakukannya, aktivitas produksi yang mereka lakukan tanpa henti dapat menghancurkan kehidupan di bumi (Smith, R. 2017: 125).

Masalah besar yang dihadapi dunia saat ini mulai kita rasakan akibatnya. Perubahan iklim terjadi hampir di semua belahan bumi, temperatur bumi terus meningkat dan lubang ozonpun semakin besar. Kualitas udara semakin memburuk yang berimplikasikan kepada berkurangnya sumber oksigen yang bersih untuk bernafas.kondisi ini juga diperparah oleh berkurangnya areal hutan alami di daerah tropis sebagai sumber penghasil oksigen bersih. Kondisi semakin diperparah oleh pemanfaatan sumber daya alam yang berlebihan sehingga merusak ekosistem makhluk hidup, habisnya sumber daya alam yang tidak dapat diperbaharui, degradasi tanah dan air, pembentukan lahan pertanian baru untuk sumber kehidupan juga telah merusak cagar alam dan merusak tanaman kehidupan makhluk hidup hewan dan tumbuhan. Kehidupan masyarakat modern, yang setiap harinya membutuhkan bahan bakar untuk sumber energi dan transportasi juga memberi sumbangan yang tidak sedikit untuk bertambahnya kerusakan lingkungan. Masyarakat moderen saat ini tidak bisa melepaskan diri untuk selalu menggunakan pendingin udara (AC), plastik, kertas, bahan pembersih rumah tangga, kosmetik dan berbagai kebutuhan hidup lainnya yang semuanya berpotensi untuk menambah pencemaran lingkungan (Santamouris).

Berbagai upaya terus dilakukan untuk mencari jalan keluar dari masalah-masalah lingkungan yang terjadi, banyak buku yang ditulis, banyak riset terus dilakukan tetapi itu juga tidak akan berarti apabila kesadaran untuk menjaga lingkungan belum ada dalam hati dan pikiran manusia (Ogunbiyi, J.O, dkk., 2009: 294). Aminrad, dkk dan Ugulu, dkk setelah melakukan riset, menegaskan bahwa dibutuhkan silabus pendidikan lingkungan di semua tingkatan pendidikan, baik formal maupun informal, yang bertujuan untuk membantu mencapai kesadaran lingkungan (Aminrad, Z., M. dkk., 2012: 1151). 
Li, J.C., menulis dalam laporan kegiatan United States Agency for International Development (USAID) bekerjasama dengan Fondation for Environmental Security \& Sustainability (FESS) yang dialksanakan pada beberapa negara berkembang di Asia Tenggara bahwa kesadaran untuk menjaga lingkungan belum menjadi prioritas di negara berkembang. Laporan ini didukung oleh hasil riset Karpudewa dan Aminrad bahwa di Asia Tenggara, seperti Indonesia dan Malaysia kesadaran lingkungan yang dimiliki warga masih rendah, dan ada kesenjangan kesadaran lingkungan yang tinggi di antara warga negara. Hasil survei Kementerian Lingkungan Hidup Indonesia (KLH), yang dilaporkan dalam buku Laporan Indeks Perilaku Peduli Lingkungan tahun 2013. Hasil survei KLH dilaksanakan terhadap penduduk Indonesia, di mana responden yang dipilih mewakili seluruh elemen masyarakat. KLH menemukan bahwa hanya $2.5 \%$ dari responden yang mendapatkan informasi tentang lingkungan melalui pembelajaran di sekolah. Ini dapat dimaknai bahwa sekolah belum berperan dalam mengembangkan kesadaran lingkungan atau dengan kata lain sekolah belum menjadi pusat pengembangan karakter peduli lingkungan. Oleh karena itu, lembaga pendidikan harus merespon temuan ini, sangat dibutuhkan peran lembaga pendidikan untuk pro aktif menjadi agen yang dapat berperan dalam mengubah mindsed masyarakat untuk sadar lingkungan. Kesadaran lingkungan melalui pembelajaran yang terintegrasi dengan pendidikan lingkungan. Meskipun kerusakan lingkungan tdak bisa dihindari, tetapi dapat diperlambat. Hal itu dapat ditempuh melalui integrasi pendidikan nilai karakter yang dapat menumbuhkan kesadaran lingkungan dalam mata pelajaran. Untuk mengubah pengetahuan, sikap dan perilaku menjadi lebih baik dapat dilakukan dengan pendidikan karakter yang menanamkan nilai-nilai. Menurut Budiansyah; Musfah; dan Vega, bahwa pendidikan karakter tidak memerlukan mata pelajaran khusus, tetapi dikembangkan melalui mata pelajaran yang ada. Semua pendidik memiliki tanggung jawab untuk menjadi agen peduli lingkungan, semua guru perlu mengaitkan pelajarannya dengan pendidikan lingkungan (Budiansyah, D, 2010: 66).

Guru perlu dan dapat mengambil peran untuk memberikan wawasan, pengetahuan dan ketrampilan untuk memiliki kepedulian terhadap lingkungan. Apalagi hampir semua hal yang berkaitan dengan pencemaran lingkungan bersumber dari bahan kimia, baik bahan kimia cair, padat maupun gas. Salah satunya, setiap hari kita membutuhkan sumber energi bahan bakar (fuel) dari bahan alam, dimana hasil pembakarannya 
mengeluarkan gas $\mathrm{CO}_{2}$ di udara, emisi gas ini beresiko meningkatkan suhu bumi. Suhu bumi diperkirakan akan terus meningkat setiap tahunnya, ini menimbulkan konsekuensi terhadap mencairnya es di laut dan juga salju di puncak gunung yang mengakibatkan volume air laut setiap tahunnya juga semakin bertambah.

Akhir-akhir ini penggunaan polimer plastik juga cukup mengkhawatirkan. Hampir tidak ada manusia yang tidak pernah menggunakan plastik, bahan kimia yang satu ini dipergunakan dalam setiap aktivitas manusia baik sebagai plastik kemasan, kantung belanja, botol minuman/softdrink, peralatan rumah tangga, pembungkus makanan, styrofoam, tas, pipa, mika, aksesoris pada kenderaan dan sebagainya. Ketergantungan kita-manusia terhadap plastik juga semakin tinggi. Meskipun tidak ada satu pun jenis plastik yang mutlak aman untuk kemasan. Penggunaan plastik sebagai kemasan pangan semakin meningkat saja seiring dengan perkembangan industri plastik. Limbah plastik ini adalah polutan yang paling berbahaya terhadap kelestarian lingkungan. Proses pelapukan plastik dan bahan kaleng soft drink membutuhkan waktu 50-100 tahun, bahkan yang mengerikan sekali bahan styrofoam tidak akan bisa busuk, tidak bisa dihancurkan oleh mikroorganisme dan tetap utuh berada di alam.

Dalam pendidikan di sekolah tersedia banyak ruang untuk memperkuat pendidikan karakter, yaitu dimensi kesadaran ilmiah metode ilmiah di dalamnya terdapat kerja ilmiah: jujur, disiplin, tanggung jawab, memiliki rasa ingin tahu yang tinggi dan lain-lain. Aspek-aspek pendidikan nilai/karakter dapat dipadukan dalam (1) materi pembelajaran, (2) kegiatan pembelajaran, (3) indikator pencapaian kompetensi, dan (4) instrumen penilaian. Terdapat banyak strategi dan metode yang dapat diadopsi untuk mengembangkan nilai melalui pembelajaran (Fisher, E.R, 2015).

Mata pelajaran kimia misalnya sebagai bagian dari pendidikan sains bukanlah hanya sekumpulan informasi belaka, melainkan juga mengandung nilai-nilai yang diberikan oleh pemakainya yaitu manusia. Belajar kimia bukan hanya untuk memahami konsep kimia saja, tetapi dengan belajar kimia mampu menjawab pertanyaan-pertanyaan yang muncul dalam kehidupan sesungguhnya (Holbork, J., 2003). Salah satu masalah masa depan yang menjadi masalah semua orang adalah masalah lingkungan hidup yang semakin hari semakin tercemar oleh bahan kimia. Untuk itu diperlukan kesadaran semua pihak untuk menghambat terjadinya pencemaran lingkungan, terutama peserta didik perlu memiliki kesadaran lingkungan yang baik, supaya dapat menjadi agen yang mampu 
menumbuh kembangkan kesadaran menjaga lingkungan di kemudian hari, begitu juga hal nya dengan pelajaran-pelajaran lain seperti pelajaran pendidikan agama Islam, karena nilai karakter kesadaran lingkungan adalah hal penting bagi semua program pendidikan di semua negara (Caduto, M. J., 1985: 2).

Bagi peserta didik sangat penting bagi mereka untuk memiliki kesadaran pentingnya menjaga dan peduli terhadap lingkungan. Penelitian yang dilakukan Teksoz mengungkapkan bahwa mahasiswa calon guru kimia belum memiliki kesadaran lingkungan yang memuaskan. Mereka tidak memiliki pengetahuan yang baik tentang issu-issu lingkungan (Teksoz, G.). Tetapi, meskipun mereka kurang memiliki pengetahuan yang diperlukan, mereka bersedia untuk mengintegrasikan isu-isu lingkungan dalam praktek pengajaran mereka. Hal yang sama penulis temukan juga dalam penelitian pendahuluan yang dilakukan terhadap peserta didik SMA Negeri 8 Banda Aceh di tempat penulis mengajar dan di beberapa sekolah yang dekat dengan sekolah penulis. Peserta didik adalah calon potensial sebagai generasi muda yang menyelamatkan bumi ini dari kerusakan bila program pendidikan karakter peduli lingkungan mereka di perkuat.

Semua lembaga pendidikan tentu memiliki tanggung jawab untuk mewujudkan pencapaian tujuan ini. Oleh sebab itu perlu diupayakan program terencana yang dapat mengimplementasi perwujudannya di sekolah menengah atas. Pendidikan harus dapat dimanfaatkan sebagai sarana pembentukan sikap dan kepedulian terhadap lingkungan secara efektif. Pendidikan yang kurang memadai dalam arti kurang memberikan informasi tentang masalah lingkungan hidup akan menyebabkan kurangnya pengetahuan yang dimiliki peserta didik yang kemudian dapat berakibat munculnya sikap kurang peduli peserta didik pada lingkungan hidup. Sebaliknya, melalui pendidikan yang intensif sangat memungkinkan untuk meningkatkan kualitas sikap perilaku yang positif terhadap lingkungan karena melaui pendidikan dapat diwujudkan kesiapan mental dan kecendrungan untuk berperilaku positif terhadap suatu objek tertentu, objek tertentu yang dimaksud itu adalah sikap dan perilaku yang positif terhadap lingkungan (Hamzah, S., 2013: 14). 


\section{Pengertian Estetika}

Istilah estetika sangat dekat dan erat hubungannya dengan kata seni, pada saat yang sama para ahli banyak yang mengkategorikan kedua hal tersebut kedalam definisi yang sama, akan tetapi tidak sedikit yang menyatakan bahwa estetika adalah sebuah bentuk dari keindahan yang berbeda dengan istilah seni. Estetika sering dihubungkan dengan sesuatu yang berbau seni karena mengandung keindahan yang dapat dipandang. Sejak kemunculannya estetika selalu digunakan untuk mengutarakan bahasa filsafat terhadap karya seni. Namun pada kenyataanya seni tidak hanya dipandang sebagai sesuatu yang indah sehingga harus ada bidang yang digunakan untuk menjawab hakekat seni sebenarnya yaitu filsafat seni.

Kata estetika sendiri berakar dari bahasa latin "aestheticus" atau bahasa Yunani "aestheticos" yang merupakan kata yang bersumber dari istilah "aishte" yang memiliki makna merasa. Estetika dapat didefinisikan sebagai susunan bagian dari sesuatu yang mengandung pola, dimana pola tersebut mempersatukan bagian-bagian yang membentuknya dan mengandung keselarasan dari unsur-unsurnya, sehingga menimbulkan keindahan. Dari hal tersebut dapat diartikan bahwa esetetika menyangkut hal perasaan seseorang, dan perasaan ini dikhususkan akan perasaan yang indah. Nilai indah yang dimaksudkan tidak hanya semata-mata mendefinisikan bentuknya tetapi bisa juga menyangkut keindahan dari isi atau makna yang terkandung didalamnya.

Dari banyaknya pemahaman yang berbeda-beda dari semua kalangan tentang apa terjemahan dari hal yang dinamakan estetika, muncullah para ahli dengan kesimpulanya sendiri dalam menanggapi apa itu pengertian dari estetika, dan berikut ini adalah pengertian dari estetika menurut para ahli dengan dilengkapi penjelasannya.

Menurut Louis Kattsof, estetika adalah cabang filsafat yang berkaitan dengan batasan rakitan (structure) dan peranan (role) dari keindahan, khususnya dalam seni (Darsono Sony Kartika, 2004: 6). Menurut Bruce Allshop estetika adalah ilmu pengetahuan yang mempelajari proses penikmatan dan aturan-aturan dalam menciptakan rasa kenyamanan. Dari definisi yang dikemukakan oleh Bruce Allsopp dalam mengartikan tentang kata estetika adalah sebuah ilmu pengetahuan, Alshopp juga menjelaskan bahwa estetika merupakan suatu kegiatan edukasi atau pembelajaran mengenai proses dan aturan tentang penciptaan sebuah karya yang nantinya akan menimbulkan perasaan nyaman bagi yang melihat dan merasakanya. 
Artini kusmiati mendefinisikan bahwa estetika adalah kondisi yang berkaitan dengan sensasi keindahan yang dirasakan seseorang tetapi rasa keindahan tersebut baru akan dirasakan apabila terjalin perpaduan yang harmonis dari elemen-elemen keindahan yang terkandung pada suatu objek. Berdasarkan pengertian yang disampaikan oleh Artini Kusmiati dapat disimpulkan bahwa yang dinamakan estetika merupakan segala hal yang memiliki sangkut paut dengan keindahan yang ada pada penglihatan seseorang, dan bagaimana seseorang dapat melihat sebuah objek, sehingga objek tersebut mempunyai nilai tersendiri dalam hati yang menikmatinya.

\section{Nilai Estetika/Keindahan}

Menurut asal katanya, "keindahan" dalam perkataan bahasa Inggris: beautiful (dalam bahasa Perancis beau, sedang Italia dan Spanyol bello yang berasal dari kata Latin bellum. Akar katanya adalah bonum yang berarti kebaikan, kemudian mempunyai bentuk pengecilan menjadi bonellum dan terakhir dipendekkan sehingga ditulis bellum. Menurut cakupannya orang harus membedakan antara keindahan sebagai suatu kwalitas abstrak dan sebagai sebuah benda tertentu yang indah. Untuk perbedaan ini dalam bahasa Inggris sering dipergunakan istilah beauty (keindahan) dan the beautifull (benda atau hal yang indah) (Darsono Sony Kartika), 2004: 2). Sedangkan menurut Thomas Aquina, keindahan berkaitan dengan pengetahuan; kita menyebut sesuatu itu indah jika sesuatu itu menyenangkan mata sang pengamat. "Keindahan harus mencakup tiga kualitas: integritas atau kelengkapan..., proporsi atau keselarasan yang benar, dan cemerlang (Mudji Sutrisno SJ, 1994: 31)".

Jadi keindahan pada dasarnya adalah sejumlah kwalita pokok tertentu yang terdapat pada sesuatu hal. Kwalita yang paling sering disebut adalah kesatuan (unity), keselarasan (harmony), kesetangkupan (symmetry), keseimbangan (balance) dan perlawanan (contrast) (Darsono Sony Kartika, 2003: 3). Ciri-ciri pokok tersebut oleh ahli pikir yang menyatakan bahwa keindahan tersusun dari berbagai keselarasan dan perlawanan dari garis, warna, bentuk, nada dan kata-kata. Ada pula yang berpendapat bahwa keindahan adalah suatu kumpulan hubungan-hubungan yang selaras dalam suatu benda dan diantara benda itu dengan si pengamat. Seorang filsuf seni dewasa ini dari Inggris bernama Herbert Read dalam (The Meaning of Art) merumuskan definisi bahwa keindahan adalah kesatuan dari hubungan-hubungan bentuk yang terdapat diantara 
pencerapan-pencerapan inderawi kita (beauty is unity of formal relations among our sense-perceptions) (Darsono Sony Kartika, 2003: 3). Keindahan bagi masing-masing orang terkadang apresiasinya tergantung pada pribadi yang bersangkutan sebab sesuatu dapat dikatakan indah namun orang lain menganggapnya tidak indah, demikian pula sebaliknya.

\section{a. Perasaan (Feeling) Keindahan}

Menurut kamus psikologi pengertian perasaan adalah Proses-proses emosional, yang disertai oleh sensasi fisik, di tingkat kesadaran yang bervariasi. Menurut NelsonJones orang dapat mengalami, mengekspresikan, dan mengelola perasaan. Perasaan adalah suatu pernyataan jiwa, yang sedikit banyak bersifat subjektif, untuk merasakan senang atau tidak senang dan yang tidak bergantung kepada perangsang dan alat-alat indra. Sedangkan menurut Hukstra, perasaan adalah suatu fungsi jiwa yang dapat mempertimbangkan dan mengukur sesuatu menurut rasa senang dan tidak senang. Menurut Koentjaraningrat (Agus Sujanto, 2015: 75), perasaan adalah suatu keadaan dalam kesadaran manusia yang karena pengaruh pengetahuannya dinilai sebagai keadaan positif dan negatif.

Perasaan selalu bersifat subjektif karena ada unsur penilaian tadi biasanya menimbulkan suatu kehendak dalam kesadaran seseorang individu. Kehendak itu bisa positif artinya individu tersebut ingin mendapatkan hal yang dirasakannya suatu yang memberikan kenikmatan kepadanya, atau juga bisa negatif artinya ia hendak menghindari hal yang dirasakannya sebagai hal yang akan membawa perasaan tidak nikmat kepadanya.

Nilai perasaan di dalam pendidikan, yaitu 1) Perasaan dapat membawa manusia ke arah kebaikan dan keburukan. Jadi dapatlah anak manusia di didik; 2) Perasaan-perasaan rohaniah dapat menimbulkan kebahagiaan bagi manusia; 3) Janganlah kita bercerita tentang sesuatu yang menakutkan atau dapat menimb ulkan rasa ngiris. Gantilah cerita semacam itu dengan cerita yang menyenangkan atau cerita-cerita pahlawan; 4) Hindarkanlah segala sesuatu yang dapat menimbulkan keburukan. 


\section{b. Kesadaran (awareness) Keindahan}

Menurut Bachmann dalam bukunya Laura A. King (2016: 180), kesadaran adalah bagian penting pengalaman manusia. Kawasan kesadaran kita mempresentasikan kondisi pikiran batin yang bersifat rahasia ketika kita berfikir, merasakan, merencanakan, berharap, berdoa, membayangkan, dan secara diam-diam mengenang kembali pengalaman. Pelopor psikologi, Wiliam James menggambarkan pikiran sebagai arus kesadaran, aliran berkelanjutan dari sensasi, gambar, pikiran perasaan yang berubah. Isi kesadaran kita berubah dari waktu ke waktu, informasi bergerak sangat cepat masuk dan keluar dari kesadaran kita.

Penelitian Rogers mengungkapkan bahwa sebelum mengadopsi perilaku baru, di dalam diri orang tersebut terjadi proses yang berurutan, yakni: awareness (kesadaran), yakni orang tersebut menyadari dalam arti mengetahui stimulus (objek) terlebih dahulu. Interes, yakni orang mulai tertarik dengan stimulus (objek), evaluation, yakni menimbang-nimbang baik atau tidaknya stimulus tersubut bagi dirinya, trial, orang telah mulai mencoba perilaku baru, adoption, subjek telah berperilaku baru sesuai dengan pengetahuan, kesadaran dan sikapnya terhadap stimulus (Syamsu Yusuf LN: 2017: 114).

Apabila penerimaan perilaku baru atau adopsi perilaku melalui proses seperti ini didasari oleh kesadaran, pengetahuan dan sikap yang positif maka perilaku tersebut akan bersifat langgeng (long lastin). Sebaliknya apabila perilaku ini bukan didasari oleh pengetahuan dan kesadaran maka tidak akan berlangsung lama.

Menurut Geller (2000) Tahapan dalam kesadaran seseorang yaitu:
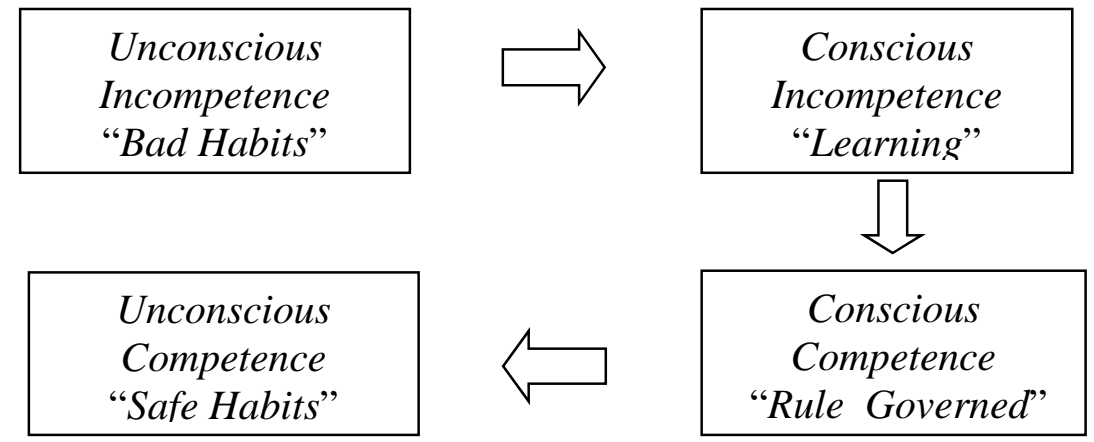

Gambar: The Do It Process Enables Shift From Bad To Goods Habbits

Berdasarkan gambar di atas tahapan-tahapan kesadaran yaitu:

1) Unconscious Incompetence, yaitu tahapan pertama dimana seseorang tidak mengerti apa yang harus dilakukannya. 
2) Conscious Incompetence, yaitu tahapan keduaa dimana seseorang mengerti atau tahu apa yang harus dilakukannya, tetapi perlu adanya pelajaran bagaimana untuk melakukannya secara benar.

3) Conscious Competence, yaitu tahapan ketiga dimana seseorang dapat melakukannya dengan benar dikarenakan telah mengikuti aturan yang telah ditetapkan.

4) Unconscious Competence, tahapan terakhir dimana seseorang telah memipunyai kebiasaan dan mengetahui secara benar apa yang dilakukannya.

Kesadaran lingkungan menurut M.T Zen adalah usaha melibatkan setiap warga negara dalam menumbuhkembangkan dan membina kesadaran untuk melestarikan lingkungan, berdasarkan tata nilai, yaitu tata nilai pada lingkungan itu sendiri dengan filsafat hidup secara damai dengan alam lingkungannya. Alam ini harus mulai ditumbuhkan melalui pendidikan sekolah dan luar sekolah, dari taman kanak-kanak hingga perguruan tinggi agar lambat laun tumbuh rasa cinta kasih terhadap alam lingkungan, disertai tanggungjawab sepenuhnya setiap manusia untuk memelihara kelestarian lingkungan.

Menurut Kaiser dalam Aminraz, bahwa kesadaran lingkungan merupakan salah satu indikator yang paling penting untuk menampilkan peradaban nasional. Hal ini mencerminkan banyak aspek status lingkungan, seperti pertimbangan pribadi dan perilaku, kapasitas masyarakat, dan sikap warga lokal terhadap masyarakat yang berkelanjutan secara keseluruhan. Selanjutnya Kogan masih dalam Amirad, menyatakan sikap peserta didik terhadap lingkungan didefinisikan sebagai keyakinan dan perasaan bahwa individu memiliki rasa terhadap lingkungan. Sikap peserta didik terhadap lingkungan dapat juga didefinisikan sebagai komitmen verbal mereka, komitmen yang sebenarnya, dan motivasi yang mempengaruhi pandangan mereka tentang alam dan masalah lingkungan.

\section{Pendidikan Estetika}

Menurut Shiller (Sunarto, 2017) pendidikan estetika adalah metode-metode atau sarana-sarana yang mengambil manajemen pendidikan untuk menumbuhkan rasa indah yang dimiliki anak, melalui kerja seni. Pendidikan estetika bukan hanya pendidikan sekolah, sesungguhnya pendidikan estetika merupakan dasar yang membuat dasar bagi 
pendidikan memberikan keseimbangan bagi individu. Akan tetapi lebih dari ini, jika memungkinkan membentuk dasar untuk membangun pribadi umat dengan kemampuan dalam menghadapi masalah-masalah dengan perbedaan tantangannya. Dan itu melalui masyarakat, orang-orang mampu mempraktekkan kehidupannya dengan kreatif, berprilaku, dan berpraktek, dan dengan gambaran yang seimbang. Dalam arti lain pendidikan estetika berarti pendidikan rasa seni dalam diri manusia, dan memastikan hubungan-hubungan estetika dengan sifat dan fenomena-fenomena kehidupan sosial.

Beberapa peneliti melihat bahwa tugas pendidikan estetika memfokuskan pengembangan kemampuan dan persiapan yang dimiliki pemuda untuk menerima setiap apa yang mengagumkan dalam tabiat, seni, dan lingkungan. Oleh karena itu pendidikan rasa estetika dan posisi estetika memiliki bangunan arah yang nyata.

\section{Peduli Lingkungan}

Peduli berarti mengindahkan; memperhatikan dan kepedulian adalah perihal sangat peduli; sikap mengindahkan (memprihatinkan) sesuatu yg terjadi di masyarakat. Sedangkan lingkungan dapat diartikan menjadi segala sesuatu yang ada di sekitar manusia dan mempengaruhi perkembangan kehidupan manusia.

Peduli lingkungan menurut Kemendiknas, adalah "sikap dan tindakan yang selalu berupaya mencegah kerusakan pada lingkungan alam di sekitarnya, dan mengembangkan upaya-upaya untuk memperbaiki kerusakan alam yang sudah terjadi”. Peduli lingkungan merupakan sikap dan perilaku yang diharapkan mampu meningkatkan kesadaran masyarakat akan pentingnya kelestarian lingkungan

Perilaku peduli lingkungan merupakan salah satu nilai moral. Menurut Lickona (1991: 21) bahwa nilai moral ada dua yaitu nilai moral dan nilai non-moral. Perilaku peduli lingkungan termasuk ke dalam kelompok nilai moral universal yang harus dimiliki oleh semua warga dunia, tidak pandang siapa dia, apa suku, bangsa dan agamanya. Masih menurut Lickona, sekolah harusnya menjadi institusi pengembang karakter. Pendidikan karakter di sekolah dapat dilakukan dengan dua prinsip: (1). Terdapatnya nilai-nilai yang bermanfaat secara objektif, disepakati secara universal yang harus diajarkan di sekolah ditengah-tengah masyarakat yang plural; (2). Sekolah-sekolah hendaknya tidak hanya mengajarkan nilai-nilai tersebut kepada para siswa, tetapi juga membantu mereka memahami, menginternalisasi, dan bertindak berdasarkan nilai-nilai tersebut (1991: 34). 
Para guru sangat penting untuk menekankan promosi kepedulian terhadap lingkungan, pengembangan kesadaran dan kepekaan terhadap lingkungan total, dan memperoleh nilai-nilai sosial untuk melindungi sumber daya alam melalui pengajaran tentang isu-isu lingkungan. Hasil penelitian mengungkapkan bahwa para guru memiliki perilaku yang menguntungkan terhadap lingkungan dan perasaan tanggung jawab pribadi untuk menciptakan lingkungan yang lebih baik. Namun, tidak semua guru memiliki pemahaman yang baik tentang isu-isu lingkungan. Meskipun mereka kurang memiliki pengetahuan yang diperlukan tetapi mereka bersedia untuk mengintegrasikan isu-isu lingkungan dalam praktek pengajaran mereka.

Berdasarkan uraian di atas pendidik perlu mengambil peran untuk dapat menghasilkan peserta didik yang memiliki wawasan pengetahuan lingkungan dan memiliki sikap dan perilaku yang baik juga dalam memperlakukan dan memanfaatkan lingkungan sebagai bagian dari ekosistem yang menopang kehidupan semua makhluk hidup. Penelitian ini suatu upaya untuk menjawab beberapa permasalahan peduli limgkungan seperti Bagaimanakah perasaan keindahan peserta didik terhadap lingkungan sekolah?, Bagaimana kesadaran keindahan peserta didik terhadap lingkungan sekolah?, Bagaimana perilaku peduli lingkungan peserta didik terhadap lingkungan sekolah?

\section{METODE PENELITIAN}

\section{Lokasi dan Pendekatan Penelitian}

Sesuai dengan fokus dan tujuan penelitian, maka penelitian ini merupakan kajian yang mendalam guna memperoleh data yang lengkap dan terperinci. Penelitian ini bertujuan untuk mendapatkan gambaran yang mendalam mengenai pendidikan estetika lingkungan sekolah menengah atas, dengan menggunakan pendekatan kualitatif. Dari kajian mendalam tersebut peneliti menarik suatu kesimpulan, sebagai sumbangan kontruksi teori baru.

Sesuai dengan sifat dan karakter permasalahan yang diangkat dalam penelitian ini, maka pendekatan penelitian kualitatif yang sesuai adalah phenomenological naturalistic, yaitu peneliti memahami dan menghayati Pendidikan Estetika Lingkungan Sekolah Menengah Atas Negeri 10 Fajar Harapan Banda Aceh pada kegiatan peduli lingkungan sekolahnya. Hal ini sebagaimana pendapat Bogdan yang menyatakan bahwa, untuk dapat 
memahami makna peristiwa dan interaksi orang, digunakan orientasi teoretik atau perspektif teoretik dengan pendekatan fenomenologik (phenomenological approach).

Data dikumpulkan dari latar yang alami (natural setting) sebagai sumber data langsung. Paradigma naturalistik digunakan karena memungkinkan peneliti menemukan pemaknaan (meaning) dari setiap fenomena sehingga diharapkan dapat menemukan local wisdom (kearifan lokal), traditional wisdom (kearifan tradisi), moral value (emik, etik dan noetik) serta teori-teori dari subjek yang diteliti. Pemaknaan terhadap data secara mendalam dan mampu mengembangkan teori hanya dapat dilakukan apabila diperoleh fakta yang cukup detail dan dapat disingkronkan dengan teori yang sudah ada. penelitian ini diharapkan dapat menemukan sekaligus mendeskripsikan data secara menyeluruh dan utuh mengenai pendidikan estetika lingkungan sekolah. Pendidikan estetika di sini meliputi keindahan lingkungan sekolah. Keindahan sekolah di sini meliputi perasaan peserta didik terhadap keindahan sekolah, kesadaran peserta didik terhadap keindahan sekolah dan perilaku peserta didik terhadap keindahan sekolah. Peneliti juga mencari data-data yang berkaitan dengan perasaan, kesadaran serta perilaku peserta didik dalam hal menjaga keindahan sekolahnya.

Sekolah yang menjadi objek penelitian adalah Sekolah Menengah Atas Negeri 10 Fajar Harapan Banda Aceh. Sekolah ini merupakan sekolah menengah yang sangat terkenal dan memiliki banyak prestasi, baik prestasi sekolah maupun prestasi yang dimiliki oleh kepala sekolahnya.

Secara aplikatif, dalam penelitian tentang pendidikan estetika lingkungan sekolah, peneliti berusaha memahami terlebih dahulu mengenai arti peristiwa atau gejala-gejala yang dimunculkan oleh peserta didik di sekolah dan juga mengamati interaksi yang terjadi antara peserta didik dan para guru pada saat berinteraksi di lingkungan sekolah. Peneliti berusaha benar-benar masuk dalam lingkungan subjek yang sedang diteliti sedemikian rupa, sehingga mudah dimengerti apa dan bagaimana suatu pengertian yang dikembangkan oleh mereka di sekitar peristiwa dalam kehidupan sehari-hari.

\section{Data dan Sumber Data Penelitian}

1. Data

Pengambilan data dalam penelitian ini dengan cara snowball sampling yaitu informan kunci menunjuk orang-orang yang mengetahui masalah yang akan diteliti untuk 
melengkapi keterangannya dan orang-orang yang ditunjuk akan menunjuk orang lain bila keterangan kurang memadai, begitu seterusnya.

Jenis data dalam penelitian ini dapat dibedakan menjadi dua, yaitu data primer dan data sekunder. Data primer diperoleh dalam bentuk kata-kata atau ucapan lisan (verbal) dan perilaku dari subjek (informan) di sekolah tersebut. Sedangkan data sekunder diperoleh dari dokumen-dokumen, foto-foto dan benda-benda yang dapat digunakan sebagai pelengkap data primer. Karakteristik data sekunder yaitu berupa tulisan-tulisan, rekaman-rekaman, gambar atau foto yang berhubungan dengan pendidikan estetika lingkungan sekolah menengah atas.

\section{Sumber Data}

Untuk mendapatkan data tersebut, peneliti perlu menentukan sumber data dengan baik, karena data tidak akan diperoleh tanpa adanya sumber data. Pemilihan dan penentuan jumlah sumber data tidak hanya didasarkan pada banyaknya informan, akan tetapi lebih dipentingkan pada pemenuhan kebutuhan data, sehingga sumber data di lapangan bisa berubah-ubah sesuai dengan kebutuhan.

Dalam penelitian ini, sumber data dibedakan menjadi dua, yaitu sumber data manusia dan sumber data bukan manusia. Sumber data manusia berfungsi sebagai subjek atau informan kunci (key informant) dan data yang diperoleh melalui informan serupa soft data (data lunak). Sedangkan sumber data bukan manusia berupa dokumen yang relevan, seperti peristiwa atau aktivitas yang ada kaitannya dengan fokus penelitian. Sedangkan data yang diperoleh melalui dokumen bersifat hard data (data keras).

\section{Teknik Pengumpulan Data}

Sesuai dengan tema penelitian diatas, maka cara pengumpulan data peneliti lakukan dengan tiga teknik, yaitu: (1) wawancara mendalam; (2) observasi partisipan; dan (3) dokumentasi. Instrumen utama pengumpulan data dalam penelitian ini adalah peneliti sendiri dengan alat bantu Hand Phone (HP), pedoman wawancara, note book dan alatalat lain yang diperlukan secara insidental. Untuk lebih jelasnya, teknik pengumpulan data yang peneliti gunakan adalah: 
1. Wawancara Mendalam

Ada dua alasan peneliti menggunakan teknik wawancara mendalam, yaitu: pertama; dengan wawancara mendalam peneliti menggali tidak saja apa yang diketahui dan dialami subjek yang peneliti teliti, tetapi juga apa yang tersembunyi jauh di dalam diri subjek tersebut. kedua; apa yang peneliti tanyakan pada informan bisa mencakup halhal yang bersifat lintas waktu yang berkaitan dengan masa lampau, masa sekarang dan juga masa akan datang.

Wawancara mendalam peneliti lakukan secara terbuka untuk menggali pandangan kepala sekolah tentang masalah yang peneliti teliti. Wawancara mendalam peneliti lakukan pada waktu dan konteks yang tepat agar mendapat data yang akurat dan peneliti lakukan berkali-kali sesuai dengan keperluan. Dalam mengadakan wawancara, peneliti dilengkapi dengan alat perekam suara (dari hand phone), dan note book untuk mencatat hal-hal yang peneliti rasa penting dan berkaitan dengan penelitian.

\section{Observasi Partisipan dan Dokumentasi}

Observasi partisipan peneliti lakukan dengan cara melibatkan diri atau berinteraksi pada kegiatan yang dilakukan oleh subjek dalam lingkungannya, mengumpulkan data secara sistematik dalam bentuk catatan lapangan.

Untuk menghemat dan menghindari kehilangan data yang telah peneliti kumpulkan dalam waktu relatif lama yang disebabkan kesalahan teknik, maka peneliti melakukan pencatatan-pencatatan secara lengkap dan secepat mungkin dalam setiap selesai pengumpulan data di lapangan. Penelitian ini merupakan jenis kualitatif, sehingga peneliti yakin bahwa pengumpulan data akan memakan waktu yang panjang.

Di samping itu data dokumen juga peneliti perlukan untuk melengkapi data yang peneliti peroleh dari wawancara mendalam dan observasi partisipan. Dokumen yang peneliti maksud berupa foto-foto sekolah, arsip-arsip sekolah, transkrip wawancara dan dokumen tentang sejarah-sejarah sekolah dan perkembangannya. Semua dokumen ini akan peneliti kumpulkan untuk kemudian peneliti analisis demi kelengkapan data penelitian. 


\section{Analisis Data}

Analisis data peneliti lakukan sebagai upaya mencari dan menata secara sistematis catatan hasil observasi partisipan, wawancara mendalam dan dokumentasi untuk meningkatkan pemahaman peneliti tentang persoalan yang peneliti teliti dan menyajikannya sebagai temuan, sedangkan untuk meningkatkan pemahaman tersebut, analisis peneliti lanjutkan dengan upaya mencari makna.

Selanjutnya dalam menganalisis data, peneliti menggunakan tiga tahapan, yaitu: (1) data reduction (reduksi data) yaitu menggolongkan, mengarahkan, membuang yang tidak perlu dan mengorganisir data; (2) data display (penyajian data) yaitu menemukan pola-pola hubungan yang bermakna serta memberikan kemungkinan adanya penarikan kesimpulan, dan (3) consclution drawing/verification (penarikan kesimpulan/verifikasi).

Dalam reduksi data, semua data lapangan dari SMA Negeri 10 Fajar Harapan Banda Aceh peneliti rangkum, dipilih hal-hal yang pokok, difokuskan pada hal-hal yang penting, dicari tema dan polanya sehingga tersusun secara sistematik dan lebih mudah dikendalikan. Jika ada data yang disajikan masih sukar untuk disimpulkan, maka proses reduksi data akan peneliti ulang kembali. Jadi reduksi data adalah bagian dari kegiatan analisis data yang peneliti lakukan selama pengumpulan data.

Data display peneliti lakukan agar data yang peneliti peroleh dan banyak jumlahnya dapat peneliti kuasai dengan dipilah-pilah secara fisik, kemudian disusun secara sistematis, dari bentuk informasi yang kompleks menjadi sederhana namun selektif. Membuat display ini juga merupakan bagian dari analisis. Setiap data yang sudah peneliti reduksi dapat penelitisajikan, dan apabila ternyata data yang peneliti sajikan belum dapat peneliti simpulkan, maka data tersebut akan peneliti reduksi kembali untuk memperbaiki sajian.

Sedangkan pengambilan kesimpulan dan verifikasi, peneliti lakukan dalam rangka mencari makna data dan mencoba untuk menyimpulkannya. Pada awalnya kesimpulan yang peneliti buat masih sangat tentatif, kabur, dan penuh keraguan. Tetapi dengan bertambahnya data dan peneliti lakukan pembuatan kesimpulan pada akhirnya akan ditemukan data penting dari lapangan penelitian. 


\section{Pengecekan Keabsahan Data}

Dalam penelitian ini, pemeriksaan keabsahan data peneliti dasarkan atas dasar kriteria-kriteria tertentu, untuk menjamin kepercayaan data yang peneliti peroleh melalui penelitian. Kriteria keabsahan data yang akan peneliti lakukan adalah seperti yang dianjurkan oleh Lincoln dan Guba, kriteria tersebut ada empat macam, yaitu 1. Kredibilitas; 2. Transferabilitas; 3. Dependabilitas; dan 4. Konfirmabilitas.

\section{HASIL PENELITIAN DAN PEMBAHASAN}

\section{Perasaan Keindahan Peserta Didik Terhadap Lingkungan Sekolah Menengah Atas}

Dari data sekolah tersebut dapat terlihat bahwa dalam pengembangan perasaan keindahan peserta didik terhadap lingkungan sekolah menengah atas tercipta dari pembiasaan yang dilakukan di sekolah dan dirumah. Sekolah tersebut dalam pengembangan perasaan keindahan peserta didik terhadap lingkungan sekolah, kepala sekolah menyusun program-program kegiatan yang berhubungan kebersihan dan keindahan lingkungan serta didukung pembiasaan yang sudah diterapkan di sekolah dan di rumah peserta didik masing-masing. Semua itu dapat dilihat dari kepekaan mereka terhadap lingkungan sekolahnya.

Kepala sekolah dalam hal pelaksanaan perawatan lingkungan sekolah dibantu oleh wakil kepala sekolah dan guru-guru yang kompeten dibidangnya, kepala sekolah terlibat langsung dalam kegiatan kepedulian lingkungan baik mengenai kebersihan, penataan taman, dan keindahan lingkungan sekolahnya.

Selain itu untuk mewujudkan lingkungan sekolah yang indah dan bersih maka kepala SMA Negeri 10 Fajar Harapan Banda Aceh menggunakan beberapa metode. Metode-metode dalam menangani kebersihan lingkungan sekolah sangat diperlukan oleh seorang pemimpin termasuk kepala sekolah, karena dengan adanya metode-metode dalam menangani kebersihan dan keindahan lingkungan, maka diharapkan kebersihan dan keindahan lingkungan sekolah dapat ditangani dengan mudah dan akan tepat sasaran dan tidak akan memunculkan masalah yang baru, atau dengan kata lain menyelesaikan masalah lingkungan dengan baik. 


\section{Kesadaran Keindahan Peserta Didik Terhadap Lingkungan Sekolah Menegah Atas}

Dari data SMA Negeri 10 Fajar Harapan Banda Aceh kesadaraan keindahan peserta didik akan timbul dalam dirinya, jika guru dan orang tua selalu mengingatkan dan memberikan contoh yang baik melalui pembiasaan. Semua itu dapat dilihat dari reflektisitas mereka pada saat melihat atau merasakan keindahan lingkungan sekolahnya.

Dari data sekolah tersebut terlihat bahwa dalam pengembangan kesadaran keindahan peserta didik terhadap lingkungan sekolah, kepala sekolah menyusun program-program kegiatan yang berhubungan kebersihan dan keindahan lingkungan serta didukung pembiasaan yang sudah diterapkan di rumah peserta didik.

\section{Perilaku Keindahan Peserta Didik Terhadap Lingkungan Sekolah Menegah} Atas

Dari data SMA Negeri 10 Fajar Harapan Banda Aceh, pembentukan rasa peduli lingkungan peserta didik akan tercipta dengan sendirinya jika guru dan orang tua selalu memberikan keteladanan dalam kehidupan sehari-hari. Semua ini dapat dilihat dari perilaku mereka pada saat memandang atau merasakan kondisi lingkungan sekolah yang tidak sesuai dengan keindahan lingkungan.

Dari data sekolah tersebut terlihat bahwa dalam pengembangan perasaan keindahan peserta didik terhadap lingkungan sekolah, kepala sekolah menyusun program-program kegiatan yang berhubungan kebersihan dan keindahan lingkungan serta didukung pembiasaan yang sudah diterapkan di rumah peserta didik.

Dari keseluruhan temuan tersebut, maka dapat peneliti simpulkan bahwa perasaan peserta didik terhadap lingkungan sekolah menengah atas dapat dilakukan dengan menggunakan teori "Cinta Lingkungan Islami” (Hubbun Darati). Adapun cara yang bisa kita lakukan agar anak terbiasa memiliki rasa cinta terhadap lingkungan dimulai sejak mereka kecil, di antaranya berkebun, dan biasakan anak untuk tidak membuang sampah sembarangan. Adapun 7 hal yang bisa bikin kamu keren dengan cara cintai lingkungan kamu, yaitu tumbler dan tempat makan sendiri; ecobag untuk mengganti kantong plastik; transportasi umum; bersepeda, atau jalan kaki; kurangi konsumsi kertas; bijak dalam menggunakan energi; dan ikut aksi lingkungan. 
Pembelajaran yang berlangsung selama ini di sekolah-sekolah belum sepenuhnya dijadikan sebagai sarana untuk mengajarkan nilai-nilai karakter (sikap) yang berkaitan dengan perilaku peduli lingkungan, sehingga dirasakan kurang mampu memberikan pemahaman secara holistik kepada peserta didik. Karena itu diperlukan rekontruksi pembelajaran karakter ke arah yang lebih holistik, futuristik, dan humanistik dengan melakukan transformasi nilai-nilai karakter dalam setiap pembelajaran sebagai upaya memupuk perilaku peduli lingkungan di kalangan peserta didik.

Tugas guru dalam proses pembelajaran bukan sekedar mampu mentransfer ilmu pengetahuan secara kognitif, tetapi juga mampu menunbuhkan nilai/sikap peduli lingkungan yang menjadi sikap hidup peserta didik secara afektif, mampu berperan sebagai pembimbing pengembang dan pengelolan kegiatan pembelajaran, serta mampu menyusun perencanaan pembelajaran sekaligus sebagai contoh dalam dalam mencapai tujuan yang telah ditetapkan.

Strategi pendukung pendidikan karakter di sekolah dapat dilakukan oleh kepala sekolah dengan langkah-langkah sebagai berikut:

1. Penataan fisik sekolah dan kelas yang kondusif untuk keberlangsungan belajar mengajar;

2. Penataan dan peningkatan kualitas kegiatan ekstrakurikuler keagamaan di sekolah;

3. Adanya pembinaan keagamaan bagi guru yang terpola dan terprogram;

4. Adanya pelatihan bagi guru tentang metode mengintegrasikan niali karakter melalui bidang studi;

5. Meningkatkan rasa tanggungjawab, disiplin, kebersamaan, persatuan, dan kerjasama dalam menjalankan aktivitas persekolahan, serta menjalin hubungan harmonis dengan sekolah atau lembaga lain;

6. Guru tampil sebagai sosok yang cerdas secara intelektual (IQ), emosional (EQ), dan spiritual (SQ);

7. Istiqamah untuk beramal saleh dan memberikan keteladanan kepada peserta didik;

8. Diantara guru lahirnya kebiasaan untuk berdiskusi, peningkatan wawasan (insight), informasi tentang ilmu umum dan agama di lingkungan tempat guru bekerja; 
9. Membudayakan ucapan salam di lingkungan di lingkungan sekolah dan lantunan ayat-ayat $\mathrm{Al}$ quran melalui radio atau pengeras suara sebelum pelajaran dimulai;

10. Adanya program BK yang berbasis nilai-nilai keimanan dan ketaqwaan; dan

11. Untuk mewujudkan masyarakat sekolah yang beradab, berbudi, menjunjung tinggi nilai-nilai, harus didukung oleh budaya lingkungan (sekolah) yang berbasis nilai.

\section{KESIMPULAN}

Pertama, perasaan keindahan peserta didik terhadap lingkungan sekolah dapat dilihat dari kepekaan mereka pada saat memandang lingkungan sekolahnya. Untuk mewujudkan perasaan peserta didik terhadap lingkungan sekolah, kepala sekolah menggunakan beberapa metode. Metode-metode tersebut yaitu: membuat lomba kebersihan dan keindahan kelas; kepala sekolah melaksanakan rencana yang telah dibuat; kepala sekolah menyediakan tong sampah dan wastafel baik di luar kelas maupun di dalam kelas. Semua program yang telah disusun dibantu oleh para pendidik dan tenaga kependidikan yang ada di sekolah. Kepala sekolah mendelegasikan tugas sesuai program yang telah disusun secara bersama-sama dalam hal lingkungan sekolah; kepala sekolah membentuk tim work yang terdiri dari Wakil kepala sekolah dan beberapa orang guru yang kompeten dibidang tersebut.

Kedua, kesadaran keindahan peserta didik terhadap lingkungan sekolah dapat dilihat dari reflektisitas mereka pada saat melihat atau merasakan keindahan lingkungan sekolahnya. Kondisi kesadaran keindahan peserta didik terhadap lingkungan sekolah memerlukan adanya peningkatan. Dengan mengacu pada kesadaran yang meliputi pengetahuan, sikap dan perilaku. Kesadaran lingkungan sekolah yang berkualitas adalah buah dari hasil kegiatan pembiasaan semua warga sekolah yang di dalamnya terdapat hubungan saling menghargai dan saling menghormati sesama warga sekolah.

Ketiga, perilaku keindahan peserta didik terhadap lingkungan sekolah dapat dilihat dari perilaku mereka pada saat memandang atau merasakan kondisi lingkungan sekolah yang tidak sesuai dengan keindahan lingkungan. Kondisi perilaku keindahan lingkungan peserta didik terhadap lingkungan sekolah memerlukan peningkatan.

Dari pelaksanaan aktivitas sehari-hari warga sekolah, maka kepala SMA Negeri 10 Fajar Harapan Banda Aceh dalam meningkatkan perasaan, kesadaran dan peduli lingkungan peserta didik dalam memandang lingkungan sekolahnya dengan menetapkan visi dan misi sekolah yang disusun secara bersama-sama dengan pendidik dan tenaga 
kependidikan serta di sosialisasikan kepada peserta didik secara terus menerus sehinga timbul rasa "Cinta Lingkungan Islami" (Hubbun Darati). Nilai-nilai cinta lingkungan Islami tersebut diantaranya adalah: tumbler dan tempat makan sendiri, ecobag untuk mengganti kantong plastik, transportasi umum, bersepeda, atau jalan kaki, kurangi konsumsi kertas, bijak dalam menggunakan energi, bijak dalam menggunakan energi, ikut aksi lingkungan. Ada beberapa cara yang bisa dilakukan agar peserta didik terbiasa memiliki rasa cinta terhadap lingkungan sejak mereka kecil, di antaranya: berkebun, dan biasakan anak untuk tidak membuang sampah sembarangan serta menanamkan kecintaan lingkungan tersebut dengan pembiasaan yang baik yang berlandaskan keislaman.

\section{DAFTAR PUSTAKA}

- Alex Sobur, Psikologi Umum, Bandung: CV. Pustaka Setia. 2016.

- Alwisol, Psikologi Kepribadian, Malang: Universitas Muhammadiyah Malang, 2016.

- A. Tafsir, Epistemologi Untuk Ilmu Pendidikan Islam, Bandung: Mimbar Pustaka, 2005.

- Agus Sujanto, Pskologi Umum, jakarta Bumi Aksara, 2015.

- Ahmad Tafsir, Epistemologi Untuk Ilmu Pendidikan Islam, Bandung: Mimbar Pustaka, 2005.

- Amos Neolaka, Kesadaran Lingkungan, Jakarta: PT. Rineka Cipta, 2008.

- Anonimus 2007, Bapepam dan Tim Penyusunan Laporan Tujuan Pembangunan Milenium (MDGs) Indonesia Tahun 2007, Laporan Perkembangan Pencapaian Millennium Development Goals Indonesia, Kementerian dan Negara Perencanaan Pembangunan Nasional/Badan Perencanaan Pembangunan Nasional, 2007.

- Budimansyah, D., Yadi R., Nandang R., Model Pendidikan Karakter di Perguruan Tinggi: Penguatan PKN, Layanan Bimbingan Konseling dan KKN Tematik di Universitas Pendidikan Indonesia, Bandung: UPI, 2010.

- Caduto, M. J., A Guide on Enviromental Values Education, Paris, UNESCO, 1985. 
- Cresswell, j.W., Qualitative Inquiry and Reseach Design-Choosing Among Five Traditions, SAGE Publication, 1998.

- Darsono Sony Kartika, Pengantar estetika, Bandung: Rekayasa Sains, 2004.

- Dwidjoseputro. Manusia dengan Lingkungannya Buku Teks Untuk Perguruan Tinggi. Jakarta: LPTK Dirjen Pendidikan Tinggi Departemen pendidikan dan Pengajaran:1987.

- Apriana, E.A.E., 2017. Pengaruh Program Perkuliahan Biologi Konservasi Dengan Pendekatan Kontekstual Berbasis Kearifan Lokal Aceh Terhadap Peningkatan Literasi Lingkungan. JURNAL SERAMBI ILMU, 28(1).

- Elias, J. L. Moral education: secular and religious, Florida: Robert E. Krieger Publishing.Co.,Inc, 1989.

- Fatchul Mu'in, Pendidikan Karakter: Kontruksi Teoretik \& Praktik, Jogjakarta: ArRuzz Media, 2016.

- Hasan Langulung, Kreativitas dan Pendidikan Islam Analisis Psikologi dan Falsafah, Jakarta: Pustaka al- Husna, 1991.

- Hamzah, S. Pendidikan Lingkungan Sekelumit Wawasan Pengantar, Bandung: Aditama, 2013.

- Jess Feist. Teori Kepribadian, Jakarta: Salemba Humanika, 2017.

- John W. Creswell, Research Design: Pendekatan Metode Kualitatif, Kuantitatif, dan Campuran, cetakan I, Yogyakarta: Pustaka pelajar, 2010.

- John Dewey. Democracy and Education. (New York: Mac Millan Company, 1964.

- Jailani, J., Abubakar, A. and Anwar, A., 2018. Implementasi Pendekatan Science Technology Society (Sts) Pada Materi Pokok Lingkungan Hidup Sebagai Upaya Peningkatanlife Skill Siswa. JURNAL SERAMBI ILMU, 30(2), pp.132-142.

- Kartono, K., Patologi Sosial II Kenakalan Remaja, Jakarta: Rajawali, 1992.

- Lickona, Thomas. Educating For Character; How Our Schools Can Teach Respect And Responsibility. Jakarta: Bumi Aksara. 2013.

- Muchsin dan Ichsan, Kesehatan Lingkungan Untuk SGO, Jakarta: PT. Rora Karya, 1979.

- Muhammad Surya, Psikologi Pendidikan, Dirjen Dikdasmen: Direktorat Kependidikan, 2004. 
- Muslich, M., Pendidikan Karakter Menjawab Tantangan Krisis Multydimensional, Jakarta: Bumi Aksara, 2011.

- Muhmidayeli, Filsafat Pendidikan, Bandung: Refika Aditama, 2011.

- Muslim Ibrahim, Khutbah Jum'at Tentang Lingkungan, Banda Aceh: Yayasan Leuser Internasional (YLI), 2016.

- Napitupulu, A., Kebijakan Pengelolaan Lingkungan Hidup Berkelanjutan, Suatu Tinjauan Teoritis dan Praktis, Bogor: IPB Press, 2013.

- Neolaka, A, Kesadaran Lingkungan, Jakarta: Rineka Cipta, 2008.

- Oliver Leaman, Estetika Islam, Bandung: PT. Mizan Pustaka, 2005.

- Paul Suparno, Filsafat Konstruktivisme dalam Pendidikan, Jogjakarta: Konisius, 1997.

- Peraturan pemerintah Republik Indonesia, Nomor 19 Tahun 2005 tentang Standar Nasonal Pendidikan.

- Prasetyo Tri, Filsafat Pendidikan, Bandung: CV. Pustaka Setia, 2000. 